Ana VAsung

FILOZOFSKI FAKULtet SVEuČILIŠta U Zagrebu

Zagreb, HrVatska

avasung@ffzg.hr

https://doi.org/10.17234/9789531755139.32

\title{
ADINATON U ANIMALISTIČKOJ FRAZEOLOGIJI
}

U radu se kao jedan od mehanizama frazeologizacije analizira stilska figura adinaton u zoonimskim frazemima dvaju srodnih jezika - bugarskom i hrvatskom. Nad prikupljenim će se korpusom provesti semantička analiza koja uključuje tumačenje motiviranosti frazema i simbolike zoonimske sastavnice te kontrastivna analiza koja će pokazati sličnosti i razlike između bugarskih i hrvatskih zoonimskih frazema.

Ključne riječi: bugarski jezik, hrvatski jezik, adinaton, animalistička frazeologija

\section{Uvod}

Stilske figure i frazeološke jedinice imaju mnogo toga zajedničkog. Njihova je funkcija ekspresivno i slikovito izražavanje i rezultat je odstupanja od uobičajenog i jednostavnog načina govora. Frazemi su se u početku proučavali u okviru stilistike, a među prvima o njima piše upravo utemeljitelj francuske stilistike Charles Bally u djelima Précis de stylistique (1905) i Traité de stylistique française (1909).

Granica između figura i frazema vrlo je tanka, stilska će figura postati frazemom kada se ustali u govoru, postane frekventna u upotrebi i općeprihvaćena i kada kao sveza riječi postane dio rečeničnog ustrojstva.

U frazeološkim se radovima često ističe da frazemi nastaju na temelju stilskih figura poput metafore, poredbe, metonimije, sinegdohe, hiperbole i sl. Metafora se ovdje nameće kao nadređeni pojam pa pojedini autori smatraju da su sve ostale figure samo podtipovi metafore, dok se u okviru kognitivne lingvistike metafora promatra kao misaoni proces na temelju kojega se formira ustaljena veza između koncepata, a ne između riječi. I poredba je primjer stilske figure koja je prešla u frazeološki fond i postala poseban strukturni tip frazema - poredbeni frazem (Fink-Arsovski 2002: 10). Određene se figure mogu povezati s tematskim grupama frazema. Prema Mokienkovu mišljenju (1980: 133) animalistički i fitonimski frazemi tijesno su povezani s poredbom dok su kod somatskih frazema zastupljene metonimija i sinegdoha.

Podrobniji pregled stilskih figura kao jednog od mehanizama frazeologizacije nalazimo kod Šiljak-Jesenković u analizi bosanskih i turskih frazema. Autorica (2003: 88) razlikuje dva tipa frazeologizacije: sintaktičku i semantičku. Sintaktička frazeologizacija predstavlja ekspanziju nefrazeološke jedinice u kojemu proširak nosi frazeološko značenje (frazeosheme) ili pak redukciju zalihosnih elemenata i kondenzaciju rečenične (poslovica, izreka) pa čak i šire tekstualne strukture (anegdota, priča, vic). 
U semantičkoj frazeologizaciji frazeološko značenje nastaje na temelju slike, najčešće putem metafore, metonimije, sinegdohe i poredbe, s pomoću semantičkih figura kao što su paradoks, hiperbola, kontrast ili s pomoću akustičnih figura kao što su asonancija i rima ${ }^{1}$ (Mršević-Radović, prema: Šiljak-Jesenković 2003: 89). Ponekad je teško povezati frazem sa samo jednom stilskom figurom jer su one međusobno povezane i često se preklapaju; sinegdoha se, primjerice, može promatrati kao podvrsta metonimije, a adinaton se tumači i kao vrsta hiperbole.

\section{Adinaton - figura diskursa}

U ovom ćemo radu podrobnije analizirati frazeme koji su utemeljeni na jednoj od figura diskursa - adinatonu². U Velikom rječniku hrvatskoga jezika (Anić 2004) definiran je kao oblik perifraze u kojemu se pojmovna nemogućnost izražava prirodnom nemogućnošću, a riječ dolazi iz grčkoga i ima značenje 'nemoguće'. U Rječniku stilskih figura Bagić (2012: 3) adinaton opisuje kao argumentacijski topos za kojim se poseže kada se kani naglasiti i izrazito afektivno podertati nemogućnost da se što dogodi. Može se promatrati kao opisno iskazivanje pojma nikad, tj. kao iskaz koji nas uvjerava da se neka stvar ne može dogoditi jer ovisi o drugoj koja se nikako ne može dogoditi. Prema Bagićevu mišljenju (2012: 3) adinaton se može tretirati i kao hiperbola u ekstremu koja povezuje neshvatljive i proturječne činjenice i proizvodi nemoguće i posve nadrealne slike.

$\mathrm{Na}$ adinatonu se temelji poznata biblijska izreka lakše će deva proći kroz ušicu igle, nego bogataš ući u kraljevstvo nebesko (Lk 18,25; Mt 19,24) za koju pojedini autori tvrde da je zapravo pogrešan prijevod i nije riječ o devi (grč. kamelos) već o sidrenom užetu (grč. kamilos) (Ladan 2006: 104). U prilog toj tezi govori istraživanje izraelskih arheologa kojim je dokazano da su deve u Svetoj zemlji pripitomljene stoljećima nakon razdoblja koje se u Bibliji opisuje ${ }^{3}$. Prema drugoj teoriji u Jeruzalemu su postojala niska, uska vrata kroz koja su prolazile životinje, a zvala su se ušica igle. Deva je kroz ta vrata mogla proći samo ako bi joj se skinuo teret, a ona se spustila na koljena (Opašić 2013: 161).

O plodotvornosti te stilske figure govori i pjesma Kako živi Antuntun Grigora Viteza u kojoj u sedam strofa pronalazimo jedanaest adinatona koji opisuju nemoguće i uzaludne radnje: Antuntun u vrtu sadi jaja, mrak grabi loncem, razlupano jaje zašiva koncem, uči ribu pjevati, tjera bicikl na ispašu, zatvara prase da lovi miševe, guske hrani sijenom, a kvočku sadi da leže novce.

1 Bagić u Rječniku stilskih figura (2012) metaforu, metonimiju, sinegdohu i poredbu naziva figurama riječi ili tropima, paradoks, hiperbola i kontrast su figure misli, a asonanca i rima figure dikcije.

2 Za ovu se figuru rabe i nazivi impossibilia i adynata (usp. Curtius 1998).

3 Vijest o istraživanju izraelskih arheologa objavio je Jutarnji list na svojoj internetskoj stranici 5. veljače 2014. 


\section{Adinaton u frazemima}

U ovom će se radu analizirati bugarski i hrvatski frazemi sa zoonimskom sastavnicom $^{4}$ koji su nastali na temelju adinatona. Široku upotrebu adinatonskoga izraza potvrđuju frazeološke jedinice različitih jezika: engleskog (when pigs fy), francuskog (quand les poules auront des dents), njemačkog (wenn Schweine fliegen könnten), ruskog (когда рак на горе свистнет <, а рыба запоет>), talijanskog (quando gli asini voleranno) i španjolskog (cuando las vacas vuelen, quando gli asini voleranno) sa značenjem 'nikada's.

Semantičku jezgru navedenih frazema čini životinja (zoonim) kojoj se pripisuju nemoguća svojstva ili radnje. U engleskom, njemačkom, talijanskom i španjolskom primjeru letenje se pripisuje životinjama iz reda krupne stoke, koja ne samo da ne može letjeti već je poprilično troma i nepokretna, u francuskom kokošima rastu zubi, a u španjolskom žabama dlake. U ruskom se frazemu raku i ribi pripisuju ljudske sposobnosti - zviždanje i pjevanje. Značenje svih navedenih frazema je 'nikada'.

U slavenskim jezicima ne nalazimo istoznačne frazeme motivirane slikom leteće stoke kao u dijelu germanskih i romanskih jezika - njihovo mjesto zauzimaju fitonimski frazemi, u kojima drvo rađa nesvojstvenim (tuđim) plodom: u bugarskom кога върба poди круши, u češkom až porostou jablka na dubě, u hrvatskom kad na vrbi rodi grožđe, u makedonskom кога јавор ќе роди јаболка, u poljskom jak gruszki na wierzbie urosnq i u srpskom кад јавор јабукама роди.

\section{Adinaton u bugarskoj i hrvatskoj animalističkoj frazeologiji}

\subsection{Frazemi sa značenjem 'nikada'}

U prikupljenom korpusu bugarskih i hrvatskih dijalektnih frazema sa zoonimskom sastavnicom životinji se pripisuje njoj nesvojstvena osobina ili sposobnost. U bugarskim frazemima кога $<$ то > засвирят биволите с кавали і кога<то> засвирят славеите с кавали bivoli i slavuji sviraju kaval. Ti su frazemi i nacionalno obojeni jer za sastavnicu imaju bugarski narodni puhaći instrument.

Dva bugarska frazema sadrže vjerske elemente. Nemogućnost ostvarenja radnje u frazemu кога направят котката калугерка sa zoonimom mačka temelji se na

$4 \quad$ Na temelju stavova iznesenih na znanstvenom skupu Animalistički frazemi u slavenskim jezicima na Filozofskom fakultetu u Zagrebu 21. i 22. ožujka 2014. te razgovora s prof. E. Nedkovom i prof. I. Vidović Bolt u ovom se radu odlučujemo za termin zoonim za naziv životinje budući da je on široko zastupljen i već dugo prihvaćen u hrvatskoj frazeologiji svjesni problematičnosti toga naziva jer se on u onomastici rabi isključivo za vlastita imena životinja (usp. Brozović Rončević i Čilaš Šimpraga 2008). S druge strane, naziv animalistička frazeologija shvaćamo kao nadređeni pojam koji obuhvaća frazeme sa zoonimskom sastavnicom, frazeme sa životinjskim somatizmom, kao i one koji u dubinskoj strukturi sadrže zoonim.

5 Namjera ovoga istraživanja nije prikupiti i analizirati sve frazeme utemeljene na adinatonu već prikazati njegovu široku rasprostranjenost u različitim jezicima. Podrobnija analiza obuhvaća samo bugarske i hrvatske frazeme ekscerpirane iz rječnika i priručnika. 
odnosu dviju suprotnosti: mačke i kaluđerice. Kaluđerica je u Pravoslavnoj Crkvi monahinja, redovnica koja živi u manastiru i vodi asketski i samački život, a mačka je njezin antipod - u Bibliji je ona simbol lijenosti i požude što nisu poželjne osobine jedne monahinje.

Uz svinju se veže bugarski frazem кога $<$ то > влезе свиня (свинка) в джамия koji se temelji na islamskom poimanju svinje kao nečiste životinje. Pojam 'nikada' ovdje se opisuje nemogućnošću njezina ulaska u džamiju. Da je riječ o neutemeljenom stereotipu o prljavoj svinji govori činjenica da se, osim u Kur'anu, i u Bibliji svinja određuje kao nečista životinja koju se ne smije jesti. Prema Viskovićevu mišljenju (2009: 60) ljudi su ti koji svinju prisiljavaju da bude prljava. Naime, svinja potječe od divljih vrsta koje žive u šumama i vlažnim područjima i koje nemaju stanice za znojenje. Zbog toga ona mora ulaziti u vodu i blato kako bi zadržala tjelesnu temperaturu pa čak i u vlastiti izmet ako joj ljudi ne omoguće ništa bolje od toga.

$\mathrm{U}$ animalističkoj frazeologiji postoje dva smjera preslikavanja: zoomorfizam i antropomorfizam (usp. Visković 2009). Zoomorfizam predstavlja pridavanje životinjskih osobina ljudima, za što je primjer frazem brz kao zec, a u drugom se slučaju životinji pripisuju ljudske osobine - primjerice ljubomora psu u frazemu ljubomoran kao pas. U prikupljenim frazemima bilježimo primjere antropomorfizma u kojima se životinjama pripisuju čovjekove sposobnosti sviranja (u bugarskome frazemu когa<mo $>$ засвирят биволите с кавали, кога<то> засвирят славеите с кавали), zviždanja i pjevanja (u ruskome frazemu когда рак на горе свистнет <, а рыба запоет>). Mnogo veću skupinu čine frazemi u kojima nije prisutan čovjek, točnije preslikavanje se ovdje ne ostvaruje između čovjeka i životinje. To su primjerice leteće svinje (eng. when pigs fly, njem. wenn Schweine fliegen könnten), krave (španj. cuando las vacas vuelen), magarci (tal. quando gli asini voleranno) ili pak svinja koja se penje na drvo. Slika penjanja svinje na drvo motivacija je hrvatskim dijalektnim frazemima kad se guda uspenje na drvo i kad se prase popenje na vrbu, a sličnu motivaciju ima dijalektni frazem u bugarskome jeziku, sa zoonimskom i fitonimskom sastavnicom, когa се покачи свиня с жълти чехли на круша. Letenje i penjanje nisu primarno ljudske vještine, one su prije svega sposobnost pojedinih životinja. U navedenim se frazemima sposobnost koja je svojstvena jednoj životinji pripisuje nekoj drugoj pa možemo govoriti o svojevrsnim metamorfozama. U bugarskome su jeziku primjer i frazemi кога $<$ то > на коня израснат (пораснат) рогове і кога $<$ то > пусне конят рога u kojima se nemogućnost ostvarenja neke radnje izražava nemogućnošću rasta roga na konju. Zastupljena je i metamorfoza na relaciji pas - vuk $\mathrm{u}$ frazemima когa<mo $>$ стане въльт куче і когато бил вълка куче и с̌ijoj je pozadinskoj slici pretvaranje vuka u psa. U drugom je primjeru glagolska komponenta u prošlom vremenu i označava radnju u prošlosti koja se nikada nije ostvarila. Metamorfoza je motivacija već spomenutog španjolskog frazema cuando las ranas crien pelos te francuskog quand les poules auront des dents. 


\subsection{Frazemi sa značenjem 'raditi uzaludan posao'}

U prvoj smo skupini analizirali frazeme kojima se izražava vremenska nemogućnost $\check{c} e g a$, a ovu skupinu čine jedinice koje upućuju na uzaludne, beskorisne pa i neizvedive radnje. Već spomenuta pjesma Kako živi Antuntun Grigora Viteza vrvi upravo nemogućim radnjama. Bagić (2012: 3) kao primjer adinatona navodi frazem musti jarca u rešeto.

U hrvatskim frazeološkim rječnicima registrirano je pet frazema sa zoonimskom sastavnicom koji imaju značenje 'raditi uzaludan posao', a u bugarskom jeziku - četiri gotovo istoga značenja 'върша нещо безсмислено, искам да постигна нещо невъзможно'.

Prase je sastavnica frazema toviti (gojiti) prase uoči Božića gdje je apsurd radnje izražen hranjenjem svinje (do potrebne težine za klanje) kada je već prekasno - uoči Božića. U frazemu potkivati (šibati) lipsala konja uzaludnost radnje izražena je slikom potkivanja uginula konja (Vidović Bolt 2011: 124). Slična je slika i u bugarskim frazemima, frazem търся от мъртъв кон подкови motiviran je traženjem potkove na uginulu konju, a bilježimo i varijantu s magarcem търся от умрялото магаре петалата. U bugarskom dijalektnom frazemu търся вълна (косъм) под езика на бълхата bilježimo nerealnu sliku traženja onoga što je nemoguće naći ${ }^{6} \mathrm{i}$ to vune ispod jezika buhe, a sliku traženja kosti u psećem ležaju u frazemu търся на кучешко легло (леговище) кокал. Uzaludan posao opisuje i hrvatski frazem drobiti ćoravoj kvočki što sa slikom usitnjavanja zrnja slijepoj kvočki (Vidović Bolt 2011: 124). U križevačko-podravskom kajkavskom govoru zabilježen je frazem mačku gaće šivati ponovno s nerealnom slikom apsurdne radnje.

Frazem musti jarca $<u$ rešeto $>$ prvi put je, prema dostupnim izvorima, u obliku musti jarca nad rešetom zabilježen u zborniku hrvatskih poslovica Josipa Kekeza koji ga smješta u razdoblje između 17. i 19. stoljeća. Riječ je o veoma starom izrazu koji je u hrvatskom jeziku relativno frekventan i danas te je našao svoje mjesto u Hrvatskom frazeološkom rječniku (2003). Frazem sadrži fakultativni dio $<u$ rešeto $>$ kojim se postiže dodatna ekspresivnost i slikovitost, a zapravo je riječ o spajanju dviju apsurdnih slika. Mužnja životinje koja se inače ne može musti uzaludna je radnja koja se ovdje intenzivira rešetom ${ }^{7}$ kao predmetom koji propušta tekućinu. I u drugim jezicima bilježimo frazeme motivirane mužnjom životinja koje se ne muzu: u češkom dojit kozla, u engleskom milk the ram, u poljskom kozł doić <próżno>, u ruskom как козла доить i u njemačkom izrazu es ist zum Mäusemelken!.

Istoga su značenja frazemi motivirani slikom prenošenja vode $u$ situ te lijevanja vode u sito ili rešeto: u bugarskom нося в (c) решето вода, u češkom nabirat vodu

$6 \quad$ Primjer hrvatskoga frazema (bez zoonima) s navedenim značenjem jest tražiti iglu u stogu (plastu) sijena ili tražiti iglu u sijenu (Hrvatski frazeološki rječnik, 2003).

7 Prema Velikom rječniku hrvatskoga jezika (Anić 2003) rešeto je pomagalo mrežaste ili rupičaste površine koje služi za prosijavanje zrnja i odvajanje od otpada. 
do sita (řešetem), u hrvatskom grabiti (hvatati) vodu rešetom i lijevati vodu u rešeto, u poljskom czerpać (lać) wodę sitem ( $w$ sito), u ruskom носить воду решетом, u slovačkom nosit' vidu $v$ site, u slovenskom $v$ rešetu vodu nositi i hrvatski dijalektni frazemi livat u rešeto ${ }^{8}$ i livat / prilit u rašeto 9 .

Pretpostavljamo da je hrvatski frazem musti jarca $<u$ rešeto $>$ nastao kontaminacijom dviju slika: mužnje jarca i prenošenjem vode u rešetu ili lijevanjem vode u rešeto.

\section{Zaključak}

U analiziranim frazeološkim jedinicama bugarskoga i hrvatskoga jezika životinje su zastupljene u ulozi vršitelja ili trpitelja radnje. U pojedinim se frazemima životinji pripisuju čovjekove osobine i sposobnosti pa govorimo o antropomorfizmu, dok u većoj skupini frazema životinje prolaze neku vrstu metamorfoze. Prikupljeni se frazemi prema značenju uklapaju u dvije skupine, jedna izražava apstraktno vremensko značenje 'nikada', a druga se odnosi na uzaludnu i beskorisnu radnju. U svim je frazemima riječ o nerealnim slikama čime je postignut visok stupanj idiomatičnosti. Analizirani frazemi čine posebnu skupinu unutar animalističke frazeologije jer nemaju obilježje antropocentričnosti. Naime, frazemi sa sastavnicom životinje u većoj se mjeri odnose na čovjeka, a mnogo je manja ona skupina frazema koja se odnosi na značajke predmeta, pojave ili vremenske odnose - prema istraživanju Holandi (2010) takvih je među bugarskim frazemima sa zoonimskom sastavnicom samo $2 \%$.

\section{LITERATURA}

Brozović Rončević, Dunja; Čilaš Šimpraga, Ankica. 2008. Nacrt za zoonomastička istraživanja (na primjeru imena konja). Folia onomastica Croatica. 17: 37-58.

Bally, Charles. 1905. Précis de stylistiqu. Genève: A. Eggimann.

Bally, Charles. 1909. Traité de stylistique française. Paris: Librairie C. Klincksieck.

Curtius, Ernst Robert. 1998. Europska književnosti i latinsko srednjovjekovlje. Zagreb: Naprijed. Fink-Arsovski, Željka. 2002. Poredbena frazeologija: pogled izvana i iznutra. Zagreb: FF press. Holandi 2010 = Холанди, Райна. 2010. Зоонимната фразеология в английския и българския език. Благоевград: ЮЗУ Неофит Рилски.

Kekez, Josip. 1986. Svaki je kamen da se kuća gradi (hrvatske poslovice). Zagreb: Izdavački centar Revija.

Ladan, Tomislav. 2006. Etymologicon. Zagreb: Masmedia.

Z Zabilježen u knjizi Mire Menac-Mihalić i Antice Menac Frazeologija splitskoga govora s rječnicima (2011).

9 Zabilježen u knjizi Mire Menac-Mihalić Frazeologija novoštokavskih ikavskih govora u Hrvatskoj: s rječnikom frazema i značenjskim kazalom s popisom sinonimnih frazema (2005). 
Maresić, Jela; Menac-Mihalić, Mira. 2008. Frazeologija križevačko-podravskih kajkavskih govora s rječnicima. Zagreb: Institut za hrvatski jezik i jezikoslovlje.

Menac-Mihalić, Mira. 2005. Frazeologija novoštokavskih ikavskih govora u Hrvatskoj: s rječnikom frazema i značenjskim kazalom s popisom sinonimnih frazema. Zagreb: Institut za hrvatski jezik i jezikoslovlje - Školska knjiga.

Menac-Mihalić, Mira; Menac, Antica. 2011. Frazeologija splitskoga govora s rječnicima. Zagreb: Institut za hrvatski jezik i jezikoslovlje.

Mokienko 1980 = Мокиенко, Валерий Михайлович. 1980. Славянская фразеология. Москва: Издательство „Вышая школа“.

Ničeva 1987 = Ничева, Кети. 1987. Българска фразеология. София: Наука и изкуство.

Opašić, Maja. 2013. Biblizmi u hrvatskom jeziku. Doktorska disertacija. Filozofski fakultet. Sveučilište u Zagrebu. Zagreb.

Šiljak-Jesenković, Amina. 2003. Nad turskim i bosanskim frazikonom. Sarajevo: Orijentalni institut u Sarajevu.

Vidović Bolt, Ivana. 2011. Životinjski svijet u hrvatskoj i poljskoj frazeologiji I. Zagreb: Hrvatska sveučilišna naklada.

Visković, Nikola. 2009. Kulturna zoologija. Zagreb: Naklada Jesenski i Turk.

\section{RJEČNICI}

Anić, Vladimir. 2003. Veliki rječnik hrvatskoga jezika. Zagreb: Novi Liber.

Bagić, Krešimir. 2012. Rječnik stilskih figura. Zagreb: Školska knjiga.

Matešić, Josip. 1982. Frazeološki rječnik hrvatskoga ili srpskog jezika. Zagreb: Školska knjiga.

Menac, Antica; Fink-Arsovski, Željka; Venturin, Radomir. 2003. Hrvatski frazeološki rječnik. Zagreb: Naklada Ljevak.

Nanova 2005 = Нанова, Ани. 2005. Фразеологичен синонимен речник на българския език. София: Хейзъл.

Ničeva 1974 = Ничева, Кети et al. 1974-1975. Фразеологичен речник на българския език. sv. I-II. София: Издателство на Българска академия на науките. 


\section{SUMMARY}

\section{ADYNATON IN THE ANIMALISTIC PHRASEOLOGY}

The paper analyzes the figure of speech adynaton in animalistic Bulgarian and Croatian idioms, as one of the mechanisms of phraseologization. Adynaton figures are strongly expressive and figurative and often appear in every type of communication. Idioms are considered those adynatons which appear frequently in speech and are used as compact structures. Intention of those expressions it to indicate that something is highly unlikely ever to happen, so their meaning is 'never' (кога<то> засвирят биволите с кавали, kad se guda uspenje na vrbu) or they express meaningless, stupid or thoughtless actions (musti jarca и rě̌eto, търся на кучешко легло (леговище) кокал. Idioms which can be explained by this figure of speech often contain animal as subject or patient of action, which contributes to their metaphoric expressivity and figurativity.

Key words: idioms, Bulgarian, Croatian, adynaton, animalistic phraseology 